\title{
Characterization of particulate matter emissions from on-road gasoline and diesel vehicles using a soot particle aerosol mass spectrometer
}

\author{
T. R. Dallmann ${ }^{1,}$, T. B. Onasch ${ }^{2}$, T. W. Kirchstetter ${ }^{1,3}$, D. R. Worton ${ }^{4,5}$, E. C. Fortner ${ }^{2}$, S. C. Herndon ${ }^{2}$, E. C. Wood ${ }^{6}$, \\ J. P. Franklin ${ }^{2, * *}$, D. R. Worsnop ${ }^{2}$, A. H. Goldstein ${ }^{1,4}$, and R. A. Harley ${ }^{1}$ \\ ${ }^{1}$ Department of Civil and Environmental Engineering, University of California, Berkeley, CA 94720-1710, USA \\ ${ }^{2}$ Aerodyne Research, Inc., Billerica, MA 01821, USA \\ ${ }^{3}$ Environmental Energy Technologies Division, Lawrence Berkeley National Laboratory, Berkeley, CA 94720, USA \\ ${ }^{4}$ Department of Environmental Science, Policy and Management, University of California, Berkeley, CA 94720-1710, USA \\ ${ }^{5}$ Aerosol Dynamics, Inc., Berkeley, CA 94710, USA \\ ${ }^{6}$ Department of Public Health, University of Massachusetts, Amherst, MA 01003-9303, USA \\ *now at: Center for Atmospheric Particle Studies, Carnegie Mellon University, Pittsburgh, PA 15213-3890, USA \\ ** now at: Department of Civil and Environmental Engineering, Massachusetts Institute of Technology, \\ Cambridge, MA 02139, USA
}

Correspondence to: R. A. Harley (harley@ce.berkeley.edu)

Received: 17 December 2013 - Published in Atmos. Chem. Phys. Discuss.: 14 February 2014

Revised: 24 May 2014 - Accepted: 10 June 2014 - Published: 29 July 2014

\begin{abstract}
Particulate matter (PM) emissions were measured in July 2010 from on-road motor vehicles driving through a highway tunnel in the San Francisco Bay area. A soot particle aerosol mass spectrometer (SP-AMS) was used to measure the chemical composition of PM emitted by gasoline and diesel vehicles at high time resolution. Organic aerosol $(\mathrm{OA})$ and black carbon (BC) concentrations were measured during various time periods that had different levels of diesel influence, as well as directly in the exhaust plumes of individual heavy-duty (HD) diesel trucks. BC emission factor distributions for HD trucks were more skewed than OA distributions $(N=293)$, with the highest $10 \%$ of trucks accounting for 56 and $42 \%$ of total measured BC and OA emissions, respectively. OA mass spectra measured for HD truck exhaust plumes show cycloalkanes are predominate in exhaust OA emissions relative to saturated alkanes (i.e., normal and isoparaffins), suggesting that lubricating oil rather than fuel is the dominant source of primary organic aerosol (POA) emissions in diesel vehicle exhaust. This finding is supported by the detection of trace elements such as zinc and phosphorus in the exhaust plumes of individual trucks. Trace elements were emitted relative to total $\mathrm{OA}$ at levels that are consistent
\end{abstract}

with typical weight fractions of commonly used additives present in lubricating oil. A comparison of measured OA and $\mathrm{BC}$ mass spectra across various sampling periods revealed a high degree of similarity in $\mathrm{OA}$ and $\mathrm{BC}$ emitted by gasoline and diesel engines. This finding indicates a large fraction of OA in gasoline exhaust is lubricant-derived as well. The similarity in $\mathrm{OA}$ and $\mathrm{BC}$ mass spectra for gasoline and diesel engine exhaust is likely to confound ambient source apportionment efforts to determine contributions to air pollution from these two important sources.

\section{Introduction}

On-road motor vehicles, especially those with diesel engines, are important sources of fine particulate matter $\left(\mathrm{PM}_{2.5}\right)$ emissions (Dallmann et al., 2010). Exposure to $\mathrm{PM}_{2.5}$ has been linked to various negative health effects (Pope and Dockery, 2006; Brook et al., 2010). $\mathrm{PM}_{2.5}$ emissions from motor vehicles are of particular importance in urban areas where emissions occur in close proximity to exposed populations (Jerrett et al., 2005; Brugge et al., 2007). For example, the fraction of 
primary emissions that is inhaled by people is approximately an order of magnitude greater for vehicles operating in urban areas compared to coal-fired power plants that have tall stacks and tend to be in more remote locations (Evans et al., 2002; Marshall et al., 2005). Motor vehicle exhaust $\mathrm{PM}_{2.5}$ is primarily composed of carbonaceous species, including black carbon (BC) and organic aerosol (OA). The relative abundance of $\mathrm{BC}$ depends on various factors, including engine type, engine operating conditions, and the presence of emission control equipment (Chow et al., 2011). In general, diesel engines tend to have higher $\mathrm{BC}$ emission rates relative to OA, and conversely for gasoline engines (Ban-Weiss et al., 2008; Chow et al., 2011).

Exhaust OA emissions consist of low volatility organic compounds derived from fuel and lubricating oil. Recent studies of emissions from combustion sources have shown that exhaust $\mathrm{OA}$ is semi-volatile, and undergoes gas-particle phase partitioning (Robinson et al., 2007; Grieshop et al., 2009). Partitioning of semi-volatile organic compounds (SVOC) between the condensed and gas phases is thought to be governed by absorptive partitioning in the atmosphere (Pankow, 1994) and therefore depends on temperature, concentrations of the condensed organic phase, and the SVOC volatility distribution (Donahue et al., 2006; Robinson et al., 2010). In the case of motor vehicle emissions, where BC/OA ratios are typically higher than observed in the atmosphere, sorption of organic compounds to BC particle surfaces may also influence gas-particle partitioning (Roth et al., 2005). Upon emission, rapid cooling of motor vehicle exhaust promotes condensation of organic vapors and partitioning is shifted towards the particle phase. As exhaust is diluted with ambient air, concentrations of gaseous SVOC are reduced, leading to evaporation of SVOC to maintain phase equilibrium (Robinson et al., 2010). Measurements of OA emission factors for motor vehicles are thus dependent on dilution and temperature conditions of the sampled exhaust (Lipsky and Robinson, 2006; Grieshop et al., 2009).

The relative contributions of diesel fuel and lubricating oil to OA emissions depend on fuel and lubricating oil properties, temperature, engine operating speed, engine load, and engine age and condition (Kweon et al., 2003; Lapuerta et al., 2003; Sakurai et al., 2003; Brandenberger et al., 2005; Maricq, 2007). Several laboratory and on-road investigations of diesel exhaust using aerosol mass spectrometers and similar instruments have concluded that lubricating oil is the dominant source of exhaust OA, based on comparisons of OA mass spectra for diesel exhaust, diesel fuel, and lubricating oil (Tobias et al., 2001; Sakurai et al., 2003; Canagaratna et al., 2004, Worton et al., 2014). Other researchers employing apportionment methods utilizing molecular markers to distinguish between fuel and lubricant-derived OA report larger contributions from fuel (Kleeman et al., 2008; Sonntag et al., 2012). The divergent findings reported in the literature on the nature and sources of primary organic aerosol emissions in motor vehicle exhaust are not easily reconciled.
Minor components of motor vehicle exhaust PM include inorganic species such as sulfate and other trace elements (Kittelson et al., 2006; Maricq, 2007). Sulfur is present as an impurity in fuel and is also used in additives found in lubricating oil. Trace elements, including zinc, phosphorus, calcium, and magnesium are commonly used in lubricating oil additives (Cadle, 1997; Spikes, 2004; Maricq, 2007). Emission rates of these trace elements in exhaust PM are low relative to carbonaceous species. However, trace metals may enhance the toxicity of particles emitted by motor vehicles (Gerlofs-Nijland et al., 2007; Bell et al., 2009). Also, for diesel engines, emissions of lubricant-derived elements are the focus of increasing scrutiny due to their potential negative effects on the performance of advanced emission control systems such as diesel particle filters. Lubricant-derived trace elements are not effectively removed during normal filter regeneration processes and thus have a tendency to form incombustible ash deposits on particle filters, which may degrade the performance and durability of these new control technologies (Sappok and Wong, 2011; Cross et al., 2012).

The primary objective of this study is to characterize the chemical composition of motor vehicle exhaust particulate matter emissions using a soot particle aerosol mass spectrometer. Individual chemical components of the exhaust PM emitted by large numbers of in-use gasoline and dieselpowered vehicles were measured to determine the composition of vehicular PM emissions, and to investigate the origins of OA emitted in diesel exhaust. This study also presents novel measurements made at high time resolution of lubricant-derived trace elements in the exhaust plumes of individual diesel trucks.

\section{Methods}

\subsection{Field measurement site}

Motor vehicle emissions were measured in July 2010 at the Caldecott tunnel in Oakland, CA. These measurements were made as a part of a study that also quantified gas and particle phase pollutant emission factors for heavy-duty (HD) diesel trucks (Dallmann et al., 2012) and light-duty (LD) gasoline vehicles (Dallmann et al., 2013). All measurements of the exhaust particle emissions described here were made in bore 1 of the tunnel, which carries a mix of gasoline-powered passenger vehicles as well as medium-duty (MD) and HD diesel trucks. MD trucks are defined in this study as those with two axles and six tires (i.e., four tires on the rear axle). HD trucks are defined as those having three or more axles. Further information on the vehicle classification system used here can be found in Dallmann et al. (2013). The tunnel is $1 \mathrm{~km}$ long and bore 1 contains two lanes of eastbound traffic, with vehicles driving uphill on a $4 \%$ roadway grade. Sampling was conducted on 4 weekdays (22, 23, 26, 27 July) and 2 weekend 
days (24, 25 July), with analytical instrumentation operating from 10 a.m. -6 p.m. each day.

As described in Dallmann et al. (2012), measurements of individual diesel exhaust plumes were made throughout the day on each of the 4 weekdays. In addition, $2 \mathrm{hr}$ intensive operating periods (IOPs) were specified for each day of sampling, during which vehicles were counted and classified, and filter samples of particulate matter were collected. Sampling dates and times were chosen to study the impact of varying levels of diesel truck traffic on tunnel pollutant concentrations and emission factors. Two IOPs were conducted on each weekday, from 12-2 p.m. and 4-6 p.m. On the weekend, there was only one IOP per day, from $2-4 \mathrm{p} . \mathrm{m}$. The midday (12-2 p.m.) IOPs on weekdays corresponded to the highest levels of diesel truck traffic in bore 1, measured both by absolute numbers of trucks and as a fraction of total vehicle counts. LD vehicle activity was highest during the weekday late afternoon (4-6 p.m.) IOPs, which led to a relatively low diesel truck fraction during these times. While LD vehicle traffic volumes during the weekend IOPs were similar to weekday levels, diesel truck traffic activity was much lower on the weekend.

\subsection{Measurement methods}

A new soot particle aerosol mass spectrometer (SP-AMS) described by Onasch et al. (2012) was used in this study to measure PM mass concentrations and chemical composition. The SP-AMS adds a $1064 \mathrm{~nm}$ continuous wave intracavity laser vaporizer to an existing Aerodyne high resolution aerosol mass spectrometer (HR-AMS). In the standard HR-AMS configuration, sampled particles are focused into a narrow beam using an aerodynamic lens. This particle beam is transmitted through a vacuum system to a resistively heated tungsten vaporizer at $600^{\circ} \mathrm{C}$, on which particles impact and vaporize. Neutral molecules formed by the vaporization of non-refractory particle components (e.g., organic compounds, ammonium, sulfate, nitrate) are subsequently ionized by $70 \mathrm{eV}$ electron impact ionization and detected by high resolution time-of-flight mass spectrometry (Jayne et al., 2000; DeCarlo et al., 2006). In the standard HR-AMS, lower volatility refractory materials such as black carbon (BC) are not vaporized at the operating temperatures of the tungsten vaporizer and, thus, are not detected by the instrument.

The inclusion of a laser vaporization source in the SPAMS enables the characterization of refractory particles in addition to the standard components (e.g., organics, sulfate, nitrate, ammonium). The laser cavity is incorporated into the AMS vacuum chamber perpendicular to the incident particle beam. As particles cross the laser beam, absorbing BC particles heat up to several thousand kelvin before vaporizing into neutral carbon clusters (Onasch et al., 2012). As the BC component of sampled particles is heated by IR absorption, both $\mathrm{BC}$ and any coatings associated with these particles are va- porized and detected. Coating species may include organics, inorganics, and refractory metals. Transit times for particles passing through the laser beam are on the order of 5-20 $\mu$ s. Due to the high vacuum in the ionizer chamber and short time scales for vaporization, the likelihood of significant oxidation of particulate material is low. Particles that either do not intersect with the laser beam or that pass through the laser beam without vaporizing will impact on the tungsten vaporizer, where non-refractory components are vaporized. Ionization and detection of vapor molecules in the SP-AMS follows standard HR-AMS methods.

For the measurements presented here, both the tungsten and laser vaporizer of the SP-AMS were turned on, enabling the characterization of non-refractory PM species and refractory $\mathrm{BC}$ along with associated coatings. A focus of this project was to characterize the chemical composition of particles in individual diesel truck exhaust plumes. These truck plume events occur over short (typically $<30 \mathrm{~s}$ ) time intervals and thus, fast sampling modes for the SP-AMS were prioritized. In general, the SP-AMS was operated in the mass spectrum (MS) data acquisition mode, whereby the particle beam is alternatively transmitted and blocked using a chopper wheel. Mass spectra measured while the particle beam is blocked correspond to the instrument background and are subtracted from the mass spectra measured while the particle beam is transmitted to isolate the signal for each ensemble of sampled particles (DeCarlo et al., 2006; Kimmel et al., 2011). This operating mode enabled the characterization of particle mass spectra with a nominal time resolution of $1 \mathrm{~s}$. Instrument background measurements (i.e. particle beam blocked) were conducted for $20 \mathrm{~s}$ of every $120 \mathrm{~s}$ sampling cycle. The time-of-flight mass spectrometer was operated with ion optics in the V-mode setting, which provided a mass resolving power of 2500 at $200 \mathrm{amu}$. This resolution enabled the separation of individual chemical ions at the same nominal massto-charge $(\mathrm{m} / \mathrm{z})$ ratio in particle mass spectra.

The SP-AMS was set up in the Aerodyne mobile laboratory, which was parked at the east end of the tunnel. As described in Dallmann et al. (2012), additional instruments to characterize gas and particle-phase pollutants were set up in the mobile lab and in a ventilation duct directly above the tunnel traffic. Tunnel air samples were drawn from a position approximately $0.1 \mathrm{~m}$ below the ceiling of the traffic bore through a ventilation plenum on the floor of the ventilation duct approximately $50 \mathrm{~m}$ from the tunnel exit. Air samples were delivered continuously to instruments set up in the mobile lab through $35 \mathrm{~m}$ of $1.4 \mathrm{~cm}$ inner diameter copper tubing at a flow rate of $16.71 \mathrm{~min}^{-1}$. A URG (Chapel Hill, NC) cyclone was installed upstream of the aerosol instrumentation to remove particles with aerodynamic diameters larger than $2.5 \mu \mathrm{m}$.

Use of the long sampling line to deliver tunnel air samples to instruments located in the mobile lab led to significant diffusive losses of small particles. The particle transmission efficiency as a function of particle diameter for the 
extractive sampling technique used here was quantified using a combination of experimental measurements and theoretical calculations. A more detailed description of these methods is included in the Supplemental Information. Results indicated that there was $50 \%$ particle transmission through the sampling line for $50 \mathrm{~nm}$ diameter particles. Smaller (i.e., nuclei mode) particles were not efficiently transported through the sampling line. Sampling losses of larger particles (> $100 \mathrm{~nm}$ in diameter) are estimated to be less than $10 \%$. Previous measurements of particle size distributions at the Caldecott tunnel show that while sub-50 nm particles account for the majority (>75\%) of total particle number emissions in motor vehicle exhaust, the contribution of these ultra-fine particles to total particle volume and mass is relatively minor $(<10 \%)$ (Ban-Weiss et al., 2010). Thus, while the long sampling line used here is not well suited for describing total particle number concentrations or ultra-fine particle size distributions, characterization of particle mass concentrations and chemical composition is not expected to be significantly impacted by sampling line losses.

Additional instrumentation deployed at the Caldecott tunnel provided supporting data for the interpretation and analysis of the SP-AMS data. A full description of gas and particle phase species measured at the tunnel and corresponding instrumentation is presented in companion publications (Dallmann et al., 2012, 2013). Supporting data utilized in this study include non-dispersive infrared absorption measurements of $\mathrm{CO}_{2}$ concentration (LI-COR model LI-6262, Lincoln, NE), and BC mass concentrations measured with a multi-angle absorption photometer (MAAP, ThermoFisher Scientific model 5012, Waltham, MA). Additionally, average mass concentrations of $\mathrm{OA}, \mathrm{BC}$, and $\mathrm{PM}_{2.5}$ were quantified for each $2 \mathrm{hr}$ sampling period using thermal-optical and gravimetric analyses of collected quartz and Teflon filter samples, respectively.

\subsection{Data analysis}

The SP-AMS data were processed using standard HR-AMS software toolkits SQUIRREL (Sequential Igor Data Retrieval, version 1.52C) and PIKA (Peak Integration by Key Analysis, version 1.11C). The direct measurement provided by the SP-AMS is a summed ion rate for individual chemical species $\left(I_{s}\right.$, units of $\mathrm{Hz}=$ ions s$\left.^{-1}\right)$. This ion rate can be converted into a mass concentration $\left(C_{s}, \mu \mathrm{g} \mathrm{m}^{-3}\right)$ utilizing instrument calibrations and known sample flow rate $\left(Q=1.4 \mathrm{~cm}^{3} \mathrm{~s}^{-1}\right)$ (Jimenez et al., 2003; Allan et al., 2004; Onasch et al., 2012):

$C_{s}=\frac{\sum_{i} I_{s, i}}{\mathrm{CE}_{s} \times \mathrm{RIE}_{s} \times \mathrm{mIE}_{\mathrm{NO}_{3}} \times Q,}$

where $\mathrm{mIE}_{\mathrm{NO}_{3}}$ is the mass specific ionization efficiency for nitrate (ions measured per picogram of nitrate sampled), $\mathrm{CE}_{S}$ is the SP-AMS collection efficiency for species $\mathrm{S}$, and $\mathrm{RIE}_{s}$ is the relative ionization efficiency of species $S$, and is de- fined as the ratio of the mass specific ionization efficiency of particulate species $\mathrm{S}$ to $\mathrm{mIE}_{\mathrm{NO}_{3}}$. $\mathrm{mIE}_{\mathrm{NO}_{3}}$ was determined to be $600 \pm 120$ ions picogram ${ }^{-1}$ based on standard AMS ammonium nitrate instrument calibrations performed during the field sampling campaign. $\mathrm{RIE}_{s}$ values for nonrefractory species typically measured by HR-AMS instruments have been characterized through laboratory calibrations (Alfarra et al., 2004; Canagaratna et al., 2007). Similarly, $\mathrm{RIE}_{B C}$ was experimentally determined to be $0.2 \pm 0.1$ based on laboratory calibrations using aerosolized Regal black particles (Onasch et al., 2012).

The laser vaporization source utilized in the SP-AMS extends the range of chemical species detected by the instrument to include refractory species associated with $\mathrm{BC}$ containing particles, such as metals derived from lubricating oil additives. Experimentally derived $\mathrm{RIE}_{s}$ values are not available for these species. For ions generated by electron impact ionization, $\mathrm{RIE}_{s}$ values can be estimated from electron impact ionization cross sections and number of electrons for the species of interest (Jimenez et al., 2003; Salcedo et al., 2012). Based on literature-reported electron impact ionization cross sections, $\mathrm{RIE}_{s}$ values for lubricant-derived trace species considered in this study are estimated as $1 \pm 0.3$ (Pottie, 1966; Tawara and Kato, 1987; Freund et al., 1990; Mozejko and Sanche, 2005). Calcium and magnesium ions may also be generated through thermal ionization mechanisms, which would result in higher than expected ion signals for these species and an overestimate of their sampled mass.

The collection efficiency in the denominator of Eq. (1) represents the fraction of sampled particles that are detected by the SP-AMS and is dependent on the chemical and physical properties of sampled particles and their interactions with the laser and tungsten vaporizers (Matthew et al., 2008). The $\mathrm{CE}$ for non-refractory species, which can be vaporized by both the laser and tungsten vaporizers, is governed by losses due to particle bounce effects at the tungsten vaporizer, and is assumed to be equal to 1 (i.e., negligible losses) for the motor vehicle exhaust emissions considered here (Slowik et al., 2004; Matthew et al., 2008; Onasch et al., 2012). The $\mathrm{CE}$ value for refractive $\mathrm{BC}$ is largely dependent on the degree of overlap in the particle and laser beams, and was estimated through comparison with a collocated MAAP instrument, as discussed below. SP-AMS collection efficiencies for lubricant-derived trace species have not yet been empirically characterized. CE values will depend on the interactions of these species with the laser and tungsten vaporizers. Species with boiling points below the operating temperature of the tungsten vaporizer (e.g., phosphoric acid, boiling (decomposition) point $=158^{\circ} \mathrm{C}$ ) are likely readily vaporized at both vaporizers and have similar $\mathrm{CE}$ values to non-refractory species. Species with boiling points above the operating temperature of the tungsten vaporizer may still generate ion signals from both vaporizers and thus have $\mathrm{CE}$ values between refractory BC (laser only) and non-refractory species. Salcedo et al. (2012) demonstrated the capability of a tungsten 
vaporizer operated at $600^{\circ} \mathrm{C}$ to vaporize zinc (boiling point $=$ $907^{\circ} \mathrm{C}$ ) in ambient air samples, though time scales for evaporation were slower than for non-refractory species. More refractory species such as calcium and magnesium (boiling point $=1484$ and $1090^{\circ} \mathrm{C}$, respectively) are likely vaporized more readily through the heating of $\mathrm{BC}$ particles at the laser vaporizer. Based on these considerations, $\mathrm{CE}$ values for the lubricant-derived trace species are estimated as unity with the same uncertainty as non-refractory species $(20 \%)$ for phosphorus/phosphate and with greater uncertainty (50\%) for zinc. Due to the higher level of uncertainty in the vaporization and ionization mechanisms for calcium and magnesium, ion signals were not converted to mass concentrations for these species.

\subsection{Diesel truck exhaust plume analysis}

The fast time response SP-AMS operating mode used for this project enabled the characterization of average mass spectra and chemical species emission factors for individual diesel truck exhaust plumes. Video recordings of vehicle activity at the tunnel on each day of sampling (weekdays only; 10 a.m. -6 p.m.) were analyzed to determine the times at which individual HD trucks passed beneath air sampling inlets. Instances where an individual truck passage resulted in a rise and fall (peak) in the measured $\mathrm{CO}_{2}$ concentration discernible above background tunnel levels were identified in previous work (Dallmann et al., 2012), and are used as the basis for further data analysis including SP-AMS results presented here. Observed $\mathrm{CO}_{2}$ concentration peaks were used to delineate the time period of exhaust plume capture for each passing truck. Corresponding peaks in measured concentrations of other pollutants are indicative of their presence in the exhaust plume, and provide information on the emission profile of each truck. In this study, mass spectra for individual trucks were obtained by subtracting the tunnel background mass spectrum measured immediately prior to sampling of a truck plume from the average mass spectrum measured during the truck plume event. Fuel-based emission factors for particulate species were calculated following the carbon balance method (Dallmann et al., 2011; 2012):

$\mathrm{EF}_{\mathrm{S}}=\frac{\int_{t_{1}}^{t_{2}}\left([S]_{t}-[S]_{t_{1}}\right) \mathrm{d} t}{\int_{t_{1}}^{t_{2}}\left(\left[\mathrm{CO}_{2}\right]_{t}-\left[\mathrm{CO}_{2}\right]_{t_{1}}\right) \mathrm{d} t} w_{\mathrm{c}}$

where $\mathrm{EF}_{S}$ is the emission factor for particulate species $\mathrm{S}$ $\left(\mathrm{g} \mathrm{kg} \mathrm{fuel}^{-1}\right.$ ) and $w_{\mathrm{c}}=0.87$ is the weight fraction of carbon in diesel fuel. The period of exhaust plume measurement is represented by the time interval $t_{1} \leq t \leq t_{2}$. $\left([S]_{t}-[S]_{t_{1}}\right)$ is the tunnel background-subtracted concentration of species $\mathrm{S}$ at time $t\left(\mu \mathrm{g} \mathrm{m}^{-3}\right)$, and similarly for $\left[\mathrm{CO}_{2}\right]\left(\mathrm{mg} \mathrm{C} \mathrm{m}^{-3}\right)$. Carbon dioxide concentrations are typically much larger than those of other carbon-containing species in diesel exhaust and thus, $\mathrm{CO}_{2}$ is used here to estimate total fuel-derived carbon associated with the exhaust plume.

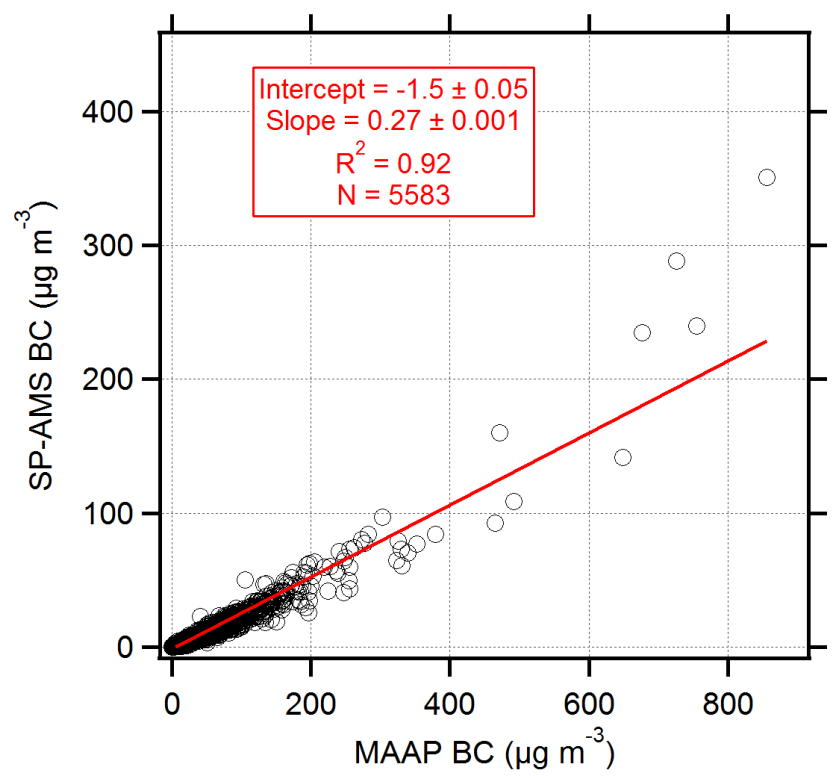

Figure 1. Comparison of $10 \mathrm{~s}$ average $\mathrm{BC}$ concentrations measured by SP-AMS and MAAP instruments. The slope of the linear fit describes the SP-AMS collection efficiency for BC as 0.27 .

\section{Results and discussion}

\subsection{Instrument intercomparisons and IOP average concentrations}

The ability of the SP-AMS to measure BC emitted by motor vehicles was evaluated through a comparison with a collocated MAAP absorption photometer. Black carbon concentrations measured with the MAAP were in good agreement with other approaches (e.g., aethalometer, photoacoustic spectrometer, thermal-optical analysis of quartz filters) used to characterize BC during this field campaign (Dallmann et al., 2012). Figure 1 shows a comparison of $10 \mathrm{~s}$ average $\mathrm{BC}$ concentrations measured by SP-AMS and MAAP for 4 of the 6 days of sampling considered here. This comparison does not include 23 or 24 July, as the MAAP was offline on those days. In general, $\mathrm{BC}$ concentrations measured by the two instruments are well correlated, with $R^{2}=0.92$ based on a linear least squares fit of the data. On average, MAAP BC concentrations are approximately 4 times larger than SP-AMS BC concentrations. In a previous application of the SP-AMS to measure particulate matter emitted by motor vehicles, Massoli et al. (2012) report an underestimate of a factor of 9 in BC concentrations measured by SP-AMS relative to the MAAP. The authors attribute this disparity to particle losses within the SP-AMS resulting from sub-optimal alignment of the laser vaporizer and particle beams. In cases where regions of the particle beam do not overlap with the laser beam, BC particles are not vaporized and thus are not detected (Onasch et al., 2012). The slope of the linear fit to the data shown in Fig. 1 therefore defines the effective 


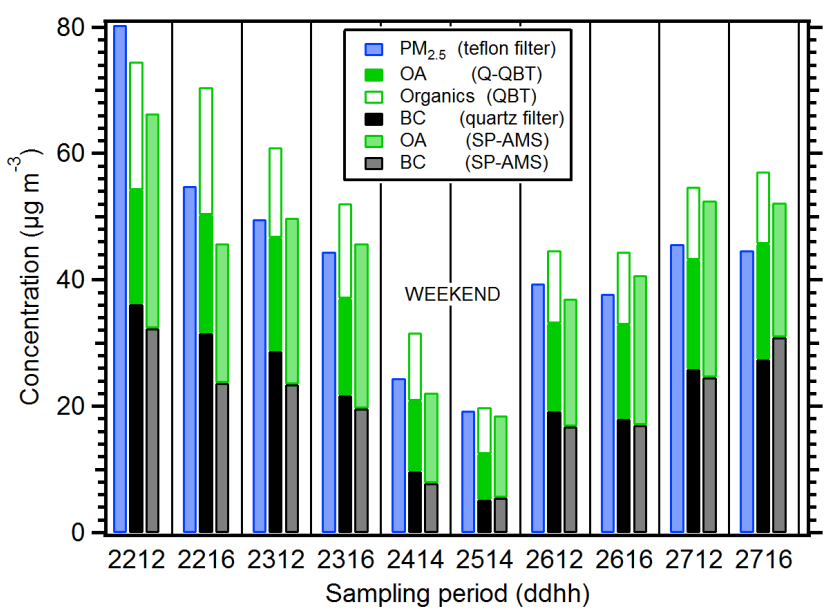

Figure 2. Comparison of average $\mathrm{PM}_{2.5}$ concentrations and composition measured during each $2 \mathrm{hr}$ sampling period. Three measures of $\mathrm{PM}_{2.5}$ mass are shown for each period, derived (reading left to right) from analysis of Teflon filters, quartz filters, and SP-AMS data. Sampling periods are identified using codes of the form ddhh, where dd indicates the day during July 2010, and hh is the starting hour of sampling. In the middle of the figure, 24 and 25 July were weekend days with lower diesel truck traffic volumes. Q-QBT OA concentrations correspond to quartz filter-derived OA measurements adjusted to account for organics measured on separate quartzbehind-Teflon (QBT) filter samples collected in parallel. QBT organic concentrations are also shown here as unshaded green bars.

collection efficiency of the SP-AMS with respect to the BC component of sampled $\mathrm{PM}, \mathrm{CE}=0.27$. Based on this analysis, SP-AMS BC mass concentrations presented here are multiplied by a factor of 3.7 (i.e., 1/CE).

SP-AMS measurements of carbonaceous aerosol mass concentrations for each IOP are shown in Fig. 2, together with corresponding measurements of $\mathrm{BC}$ and $\mathrm{OA}$ derived from thermal-optical analysis of quartz filter samples, and $\mathrm{PM}_{2.5}$ mass concentrations from gravimetric analysis of Teflon filter samples. In this figure, tunnel $\mathrm{PM}_{2.5}$, OA, and $\mathrm{BC}$ mass concentrations are shown in blue, green and black, respectively. For quartz filter OA measurements presented in Fig. 2, quartz filters located behind (i.e., downstream of) teflon filters (QBT) were used to correct for a positive sampling artifact in determining tunnel OA concentrations from front quartz filters. The positive artifact results from the adsorption of low volatility organic vapors to the quartz filters. Volatilization of collected OA from the front quartz filter may result in a negative sampling artifact, though this effect has been found to be small relative to the adsorption of organic vapors for emissions from gasoline and diesel engines (Schauer et al., 2002; Shah et al., 2004; Lipsky and Robinson, 2006; May et al., 2013). Tunnel OA concentrations were estimated by subtracting organic mass measured on QBT filters from bare quartz filters collected in parallel. Resulting OA concentrations for each IOP are shown in Fig. 2 as solid green bars (Q-QBT). The measured organic concentration derived from QBT filter samples (corresponding to adsorbed organic vapors) is shown as unshaded bars above the corrected front quartz filter OA estimates. Organic carbon mass loadings determined from the quartz filters were converted to equivalent $\mathrm{OA}$ mass by multiplying by a factor of 1.25 . This factor represents the organic aerosol to organic carbon mass ratio (OA / OC) and accounts for additional mass, mainly hydrogen, associated with organic carbon present in the particle phase. The OA / OC ratio for PM in the Caldecott tunnel was calculated using SP-AMS data following methods developed by Aiken et al. (2007, 2008). Throughout the field study, SPAMS OA concentrations were approximately $40 \%$ higher than OA concentrations derived from the corrected quartz filter samples (Q-QBT). Uncertainties in the quantification of these sampling artifacts likely contribute to the discrepancies observed in filter and SP-AMS OA measurements. For example if the volatilization of particulate organic compounds collected on front quartz filters is non-negligible, treatment of the back quartz filter OA measurements followed here may underestimate actual tunnel OA concentrations.

As shown in Fig. 2, fine particulate matter measured in the tunnel is composed primarily of carbonaceous species. The sum of $\mathrm{OA}$ and $\mathrm{BC}$ contributions estimated from quartz filter samples and the SP-AMS accounted for $87 \pm 8$ and $99 \pm 8 \%$ of Teflon filter-derived $\mathrm{PM}_{2.5}$ mass, respectively. This finding is consistent with the knowledge that motor vehicle exhaust $\mathrm{PM}_{2.5}$ is mainly composed of carbonaceous species, with minor contributions from inorganic species such as sulfate and metallic ash (Fujita et al., 2007; Maricq, 2007; Ban-Weiss et al., 2008). The largest difference between $\mathrm{PM}_{2.5}$ and carbonaceous aerosol mass concentrations was observed for the 22 July, 12-2 p.m. sampling period shown at the left of Fig. 2. During this time period, tunnel maintenance staff carried out street sweeping of the traffic lanes, which is expected to have enhanced contributions to $\mathrm{PM}_{2.5}$ from non-tailpipe sources (e.g., resuspended road dust).

Total $\mathrm{PM}_{2.5}$ mass measurements provided by the SPAMS, including carbonaceous species and inorganic ions (e.g., sulfate, nitrate, ammonium, chloride), are further compared with Teflon filter derived $\mathrm{PM}_{2.5}$ mass concentrations in Fig. 3. Excluding anomalous data from one sampling period with street sweeping activity, $\mathrm{PM}_{2.5}$ mass concentrations determined by the two methods are generally in good agreement, with a slope near one and a correlation coefficient of 0.82. Inorganic ions accounted for less than $5 \%$ of total particle mass measured by the SP-AMS during weekday IOPs, and 8 and $14 \%$ of total mass on Saturday and Sunday sampling periods, respectively, when tunnel concentrations were lower. Ammonium concentrations were well correlated with the sum of the nitrate molar concentration and the sulfate molar concentration multiplied by a factor of $2\left(R^{2}=0.98\right)$, suggesting the main source of these species was likely ammonium nitrate and ammonium sulfate present in the ambient background air drawn inside the tunnel. Motor vehicle 


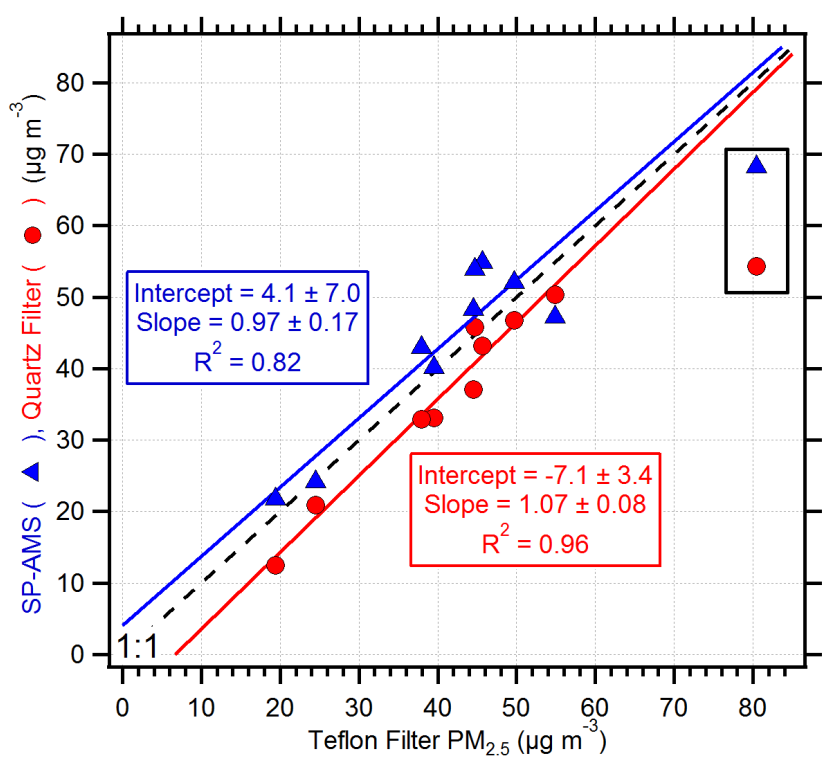

Figure 3. Comparison of gravimetrically determined $\mathrm{PM}_{2.5}$ mass concentrations and (blue triangles) SP-AMS total mass including carbonaceous species (OA, BC) as well as inorganic ions (sulfate, nitrate, ammonium, chloride), and (red circles) carbonaceous species (OA, BC) determined from thermal-optical analysis of quartz filter samples. Boxed points at the right of the figure were excluded from the regression analysis due to an anomalous street sweeping event that occurred during the IOP2212 sampling period.

contributions to inorganic ions measured in the tunnel may also result from the presence of trace impurities and additives in fuel and lubricating oil, particularly in the case of sulfate (Maricq, 2007).

\subsection{Chemical composition of diesel exhaust PM}

The concentration time-series response of the SP-AMS to a passing HD truck is shown in Fig. 4 for $\mathrm{BC}$, OA, and several elements. A clear peak in the measured $\mathrm{CO}_{2}$ concentration above background levels is visible and defines the period of exhaust plume measurement $(\sim 15 \mathrm{~s})$. Corresponding peaks in the measured $\mathrm{OA}$ and $\mathrm{BC}$ concentrations are similarly well-defined, indicating the presence of these species in the exhaust plume. Fig. 4 also shows clear peaks in several trace elements associated with diesel fuel and lubricating oil additives (Cross et al., 2012).

A prior analysis of data collected during $\sim 30 \mathrm{~h}$ of sampling over the 4 weekdays considered here identified 809 candidate HD trucks for which individual truck exhaust plume contributions of $\mathrm{CO}_{2}$ were discernible above background levels inside the tunnel (Dallmann et al., 2012). Due to a lower duty cycle relative to $\mathrm{CO}_{2}$ analyzers (i.e., frequent background checking) and more frequent instrument calibrations, SP-AMS data were only available for 293 of the 809 successful plume captures. As discussed below, this sub-sample was used to calculate emission factors for OA,

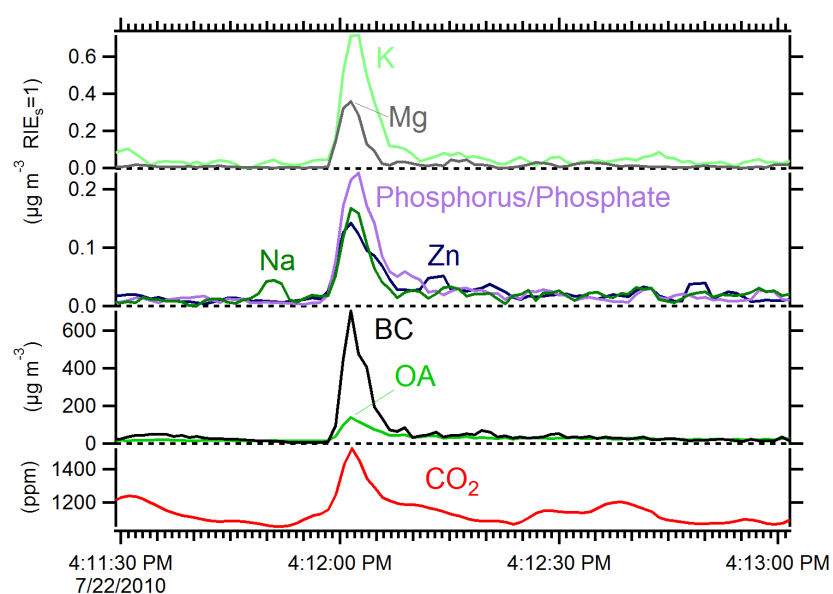

Figure 4. Species concentrations measured during individual diesel truck plume event. Clear peaks are visible for trace elements, indicating presence in truck exhaust plume.

$\mathrm{BC}$, and various trace elements from individual trucks. For the mass spectral analysis discussed here, additional criteria were defined to identify trucks for which exhaust plume PM mass spectra were sufficiently distinct from tunnel background mass spectra. In this case, only trucks with OA and $\mathrm{BC}$ emission factors greater than $0.05 \mathrm{~g} \mathrm{~kg}^{-1}$, as calculated using Eq. (2), and peak exhaust plume $\mathrm{CO}_{2}$ concentrations at minimum $100 \mathrm{ppm}$ higher than tunnel background levels (corresponding to an approximately $10 \%$ increase for typical tunnel $\mathrm{CO}_{2}$ concentrations of $1000 \mathrm{ppm}$ ) were considered for mass spectral analysis. These criteria excluded trucks with low particle mass emission rates and truck plumes that were highly dispersed in the tunnel prior to their measurement. Of the 293 trucks for which SP-AMS data were available, 145 met these acceptance criteria.

The average SP-AMS mass spectrum for this population of trucks is shown in Fig. 5, with mass spectra for carbon and organic ions shown in the lower panel and ions associated with trace elements shown in the top panel. Tunnel background-subtracted mass spectra for each truck were normalized to the total ion signal and then averaged to obtain the results shown in Fig. 5. In the average diesel PM mass spectrum, the height of each bar indicates the relative percent of the total ion signal for a given mass-to-charge ratio $(\mathrm{m} / \mathrm{z})$, and uncertainty bars show the $95 \%$ confidence interval. The use of a high-resolution mass spectrometer enabled identification of individual chemical ion contributions at the same nominal $\mathrm{m} / \mathrm{z}$ and the separation of spectra according to chemical families. Ion fragments of the family $\mathrm{C}_{\mathrm{x}}^{+}$indicate clusters of carbon atoms and represent the $\mathrm{BC}$ signal, shown in black in Fig. 5. On average, the BC signal accounted for approximately $9 \%$ of the total ion signal measured for diesel exhaust PM. The largest carbon ion signals are from the fragments $\mathbf{C}_{1}^{+}(\mathrm{m} / z=12)$ and $\mathrm{C}_{3}^{+}(\mathrm{m} / \mathrm{z}=36)$, which together account for $77 \%$ of the total carbon ion signal for $m / z$ in the 


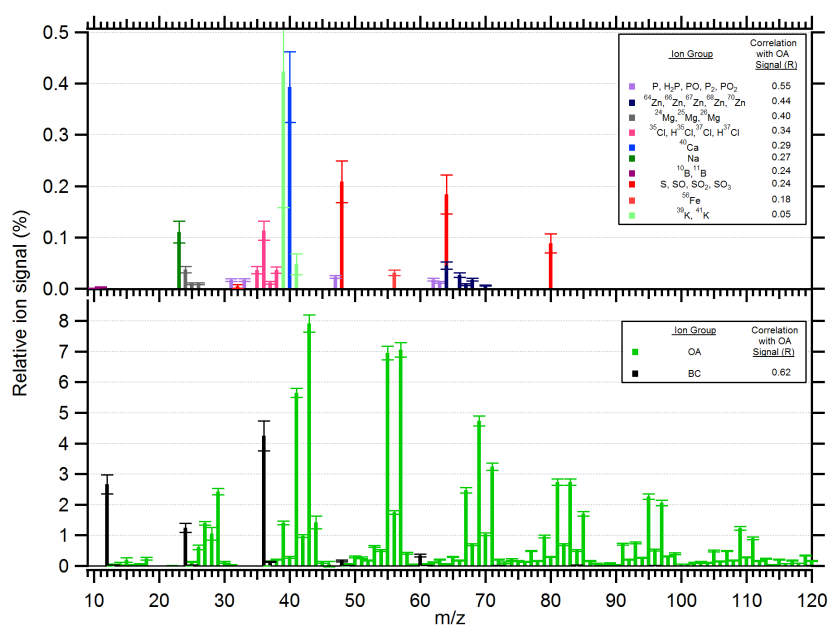

Figure 5. Average relative ion signal for 145 diesel truck exhaust plumes. Error bars show $95 \%$ confidence interval. Legend includes correlation of signal from each ion group with the total OA signal.

range 10-360. Likewise, small carbon clusters of 1-5 carbon atoms $\left(\mathrm{C}_{1}^{+}-\mathrm{C}_{5}^{+}\right)$account for greater than $97 \%$ of the total carbon ion signal in this mass range. These findings are consistent with previous measurements of $\mathrm{BC}$ mass spectra for individual diesel buses in New York City (Massoli et al., 2012).

The OA component of the diesel truck mass spectrum is dominated by hydrocarbon ion fragments of the $\mathrm{C}_{\mathrm{x}} \mathrm{H}_{\mathrm{y}}^{+}$family. The largest observed signals in the $\mathrm{OA}$ mass spectrum are from the ion fragments $\mathrm{C}_{3} \mathrm{H}_{5}^{+}(\mathrm{m} / \mathrm{z}=41), \mathrm{C}_{3} \mathrm{H}_{7}^{+}(\mathrm{m} / \mathrm{z}$ $=43), \mathrm{C}_{4} \mathrm{H}_{7}^{+}(m / z=55)$, and $\mathrm{C}_{4} \mathrm{H}_{9}^{+}(\mathrm{m} / z=57)$, which together account for 27 and $30 \%$ of the total ion and $\mathrm{OA}$ ion signals, respectively. In sum, ions of the $\mathrm{C}_{\mathrm{x}} \mathrm{H}_{\mathrm{y}}^{+}$family contributed $91 \%$ of the measured OA signal and $79 \%$ of the total ion signal. The predominance of the $\mathrm{C}_{\mathrm{x}} \mathrm{H}_{\mathrm{y}}^{+}$family in the OA mass spectrum is expected for primary exhaust $\mathrm{OA}$ from diesel engines and is consistent with previous characterizations of the chemical composition of PM emitted by in-use vehicles (Canagaratna et al., 2004; Chirico et al., 2011; Massoli et al., 2012). Organic aerosol emitted by diesel trucks is largely unoxidized, with oxidized organic ion fragments of the families $\mathrm{CHO}$ and $\mathrm{CHO}_{>1}$ contributing less than $10 \%$ of the total organic signal. Atomic ratios $(\mathrm{O} / \mathrm{C}, \mathrm{H} / \mathrm{C})$ and the organic aerosol mass to organic carbon ratio (OA/OC) of the diesel truck OA were evaluated following methods developed by Aiken et al. $(2007,2008)$. Average values of $\mathrm{O} / \mathrm{C}, \mathrm{H} / \mathrm{C}$, and $\mathrm{OA} / \mathrm{OC}$ for the diesel trucks considered here are $0.06 \pm 0.02,1.90 \pm 0.05$, and $1.24 \pm 0.03$, respectively. These values agree with other ratios measured in laboratory investigations of diesel engine exhaust (Mohr et al., 2009; Chirico et al., 2010).

Sources of OA in diesel exhaust include unburned fuel and lubricating oil and their partially oxidized products (Maricq, 2007). Though both fuel and oil are derived from petroleum sources, different processing techniques lead to large differences in the molecular weights and chemical structures. For example, diesel fuel is typically composed of hydrocarbons with carbon numbers ranging from $\mathrm{C}_{10}-\mathrm{C}_{25}$, while lubricating oils consist of less volatile hydrocarbons with carbon numbers ranging from $\mathrm{C}_{14}-\mathrm{C}_{45}$ (Tobias et al., 2001; Kweon et al., 2003; Isaacman et al., 2012). Additionally, while diesel fuels have high concentrations of $n$ alkanes, lubricating oils tend to be dominated by cycloalkanes, due to the deliberate removal of $n$ alkanes during a dewaxing process (Tobias et al., 2001; Isaacman et al., 2012).

Previous studies of diesel PM using AMS and similar instruments have investigated the relative contributions of fuel and lubricating oil to diesel exhaust OA (Tobias et al., 2001; Sakurai et al., 2003; Canagaratna et al., 2004). Three main hydrocarbon ion series were identified in both fuel and lubricating oil: (1) $\mathrm{C}_{\mathrm{n}} \mathrm{H}_{2 \mathrm{n}+1}^{+}(\mathrm{m} / z 29,43,57,71,85,99 \ldots)$ typical of saturated alkyl compounds ( $n$ alkanes, branched alkanes), (2) $\mathrm{C}_{\mathrm{n}} \mathrm{H}_{2 \mathrm{n}-1}^{+}(\mathrm{m} / z 27,41,55,69,83,97 \ldots)$ typical of unsaturated aliphatic compounds (cycloalkanes, alkenes) and (3) $\mathrm{C}_{\mathrm{n}} \mathrm{H}_{2 \mathrm{n}-3}^{+}(m / z 67,81,95,109 \ldots)$ ion fragments derived from bicycloalkanes (McLafferty and Turecek, 1993; Tobias et al., 2001; Canagaratna et al., 2004). Also, previous investigations found that saturated alkane ion signals are larger than neighboring cycloalkane-derived ion signals in the ranges $m / z=67-71$ and $81-85$ for diesel fuel, while the opposite is true for lubricating oil (Tobias et al., 2001; Sakurai et al., 2003; Canagaratna et al., 2004). In each of these prior studies, the predominance of $\mathrm{m} / z=69$ versus 71, and $m / z=83$ versus 85 , in diesel OA mass spectra indicates that the lubricating oil contribution to diesel OA dominates over contributions attributable to diesel fuel.

All three of the main hydrocarbon series noted above are apparent in the diesel truck plume OA mass spectrum measured in this study (shown in Fig. 5). Average diesel PM ion signal ratios at $\mathrm{m} / \mathrm{z}=69$ to 71 and $\mathrm{m} / \mathrm{z}=83$ to 85 were $1.51 \pm 0.08$ and $1.66 \pm 0.08$, respectively. Sakurai et al. (2003) measured particle mass spectra for diesel exhaust particles and for mixtures of varying ratios of lubricating oil to diesel fuel. Results from these experiments show ion signals at $\mathrm{m} / \mathrm{z}, 71$ and 85 were larger than signals at $\mathrm{m} / \mathrm{z}, 69$ and 83 , respectively, for mixtures containing $20 \%$ fuel: $80 \%$ oil and $10 \%$ fuel: $90 \%$ oil. Cycloalkane signals in these mass ranges were only clearly dominant over saturated alkane signals for a mixture of $5 \%$ fuel: $95 \%$ oil. Based on these results, the authors concluded that measured diesel exhaust particles, whose spectra had ratios at $\mathrm{m} / \mathrm{z}=69$ to 71 , and $\mathrm{m} / \mathrm{z}=$ 83 to 85 greater than unity, are comprised of at least $95 \%$ unburned lubricating oil. While the lack of measurements of pure fuel and lubricating oil samples preclude a similar analysis in the present study, ion ratios greater than one at $\mathrm{m} / \mathrm{z}=$ 69 to 71 and $\mathrm{m} / z=83$ to 85 support a similar conclusion that lubricating oil was the predominant source of OA measured in the exhaust of diesel trucks operating in the Caldecott tunnel. Alkenes formed from incomplete combustion of diesel 
fuel may contribute to the signal measured at $m / z=69$ and $\mathrm{m} / \mathrm{z}=83$, though this contribution is expected to be minor relative to the cycloalkane signal (Worton et al., 2014).

Further information concerning the origin of OA in the exhaust of the $145 \mathrm{HD}$ diesel trucks considered here is derived through an analysis of other trace elements measured in individual exhaust plumes. Trace elements included in this analysis were selected based on their inclusion in lubricating oil and on their prior identification in diesel exhaust PM in a laboratory study that used the SP-AMS (Cross et al., 2012). These trace species are typically present as additives or impurities in diesel fuel and lubricating oil. For example, zinc and phosphorus are present in zinc dialkyl dithiophosphate (ZDDP), a widely used lubricating oil additive that enhances anti-wear and antioxidant properties of the oil (Spikes, 2004). Similarly, calcium and magnesium are components of detergent additives in lubricating oils (Cadle et al., 1997). Lubricating oil additives such as calcium, zinc, and phosphorus are typically not present at detectable levels in diesel fuel, and can thus be used as tracers for lubricant-derived OA in diesel exhaust (Spencer et al., 2006; Shields et al., 2007). Sulfur is present both as a trace species in diesel fuel, as well as in lubricating oil additives. Other species considered here include potassium and sodium associated with diesel fuel, and lead associated with engine wear (Cross et al., 2012). While these trace elements typically account for a small fraction of the total PM mass emitted by diesel engines, trace element emissions may accumulate over time and negatively affect the performance of diesel particle filters, as ash deposits related to these species are not readily removed from exhaust filters by oxidative regeneration schemes that are used to remove accumulated BC and OA (Maricq, 2007; Sappok and Wong, 2011).

The top panel of Fig. 5 shows the average relative ion signal measured for trace elements in the exhaust of diesel trucks operating at the Caldecott tunnel. The mass resolving power of the high resolution time-of-flight mass spectrometer used in the SP-AMS enabled the simultaneous identification of these trace elements and hydrocarbon fragments at the same nominal $\mathrm{m} / \mathrm{z}$. Included in the legend are the correlation coefficients for a comparison of the summed ion signal for each ion group with the total OA signal across the sampled population of trucks. For trace elements, the highest correlation with OA was observed for lubricant-derived species, including phosphorus containing ions (phosphorus/phosphate), zinc, and magnesium. Figure 4 shows an example of a truck plume where signals for these species were particularly strong and readily discernible above both background signals and SP-AMS instrument noise. Emission mechanisms for lubricating oil include volatilization of oil components at high temperatures and liquid oil emissions (Tornehed and Olofsson, 2011). In Fig. 4, the correspondingly large BC signal suggests these elements were likely associated with $\mathrm{BC}$ particles and vaporized as a result of the heating of laser-light absorbing $\mathrm{BC}$ particles. Across the sampled truck population,

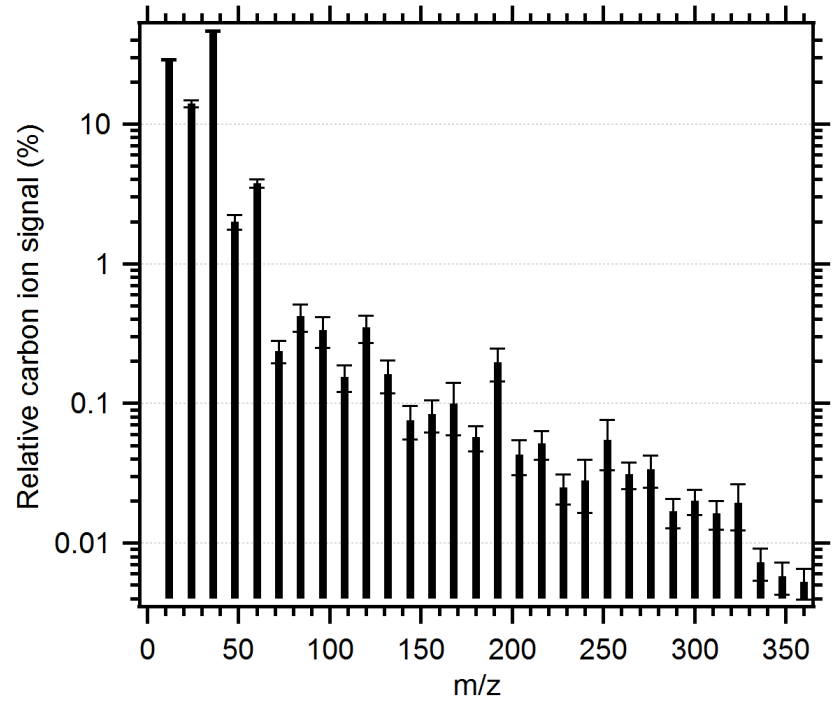

Figure 6. Average BC mass spectrum for 145 diesel truck plumes. Ion signals for each carbon ion $\left(\mathrm{C}_{\mathrm{X}}^{+}\right)$are normalized to total carbon ion signal. Note ${ }^{13} \mathrm{C}$ isotopes are excluded here for sake of visual clarity.

the identification of lubricant-derived species in exhaust PM is further supported by a positive correlation $\left(R^{2}=0.71\right)$ between the average plume phosphorus/phosphate and zinc signals, suggesting a common source for both of these trace elements. The presence of lubricant-derived trace metal species in diesel exhaust plumes and their positive correlation with OA further suggests lubricating oil as a major contributor to diesel OA emissions.

In Fig. 5, a clear signal for calcium, another common lubricating oil additive, is visible at $\mathrm{m} / \mathrm{z}=40$, though the correlation with $\mathrm{OA}$ is weaker than for other lubricant-derived elements. Uncertainties arose in the definition of the exhaust plume calcium $\left({ }^{40} \mathrm{Ca}\right)$ signals due to interferences from the gas phase argon (Ar) signal at the same $m / z$. The mass resolving power of the SP-AMS was not sufficient to differentiate ${ }^{40} \mathrm{Ca}$ from ${ }^{40} \mathrm{Ar}$. Argon levels in tunnel air are expected to be relatively stable, thus for this analysis signals for ${ }^{40} \mathrm{Ca}$ and ${ }^{40} \mathrm{Ar}$ were summed and any increase in the combined signal above baseline levels was assumed to represent a contribution from ${ }^{40} \mathrm{Ca}$. Uncertainties due to the higher baseline signal in this approach may explain the larger diesel truck exhaust signal for calcium relative to other lubricant-derived species, as well as the weaker correlation with OA.

The average diesel truck BC mass spectrum, normalized to total carbon ion signal, is shown in Fig. 6. A key feature of this spectrum is the low variability in the distribution of carbon ion signals across the sampled truck population, as evidenced by the relatively small uncertainty in contributions to the total signal associated with each carbon ion. This low variability suggests that the distribution shown in Fig. 6 could define a BC emissions source "fingerprint" for in-use diesel 

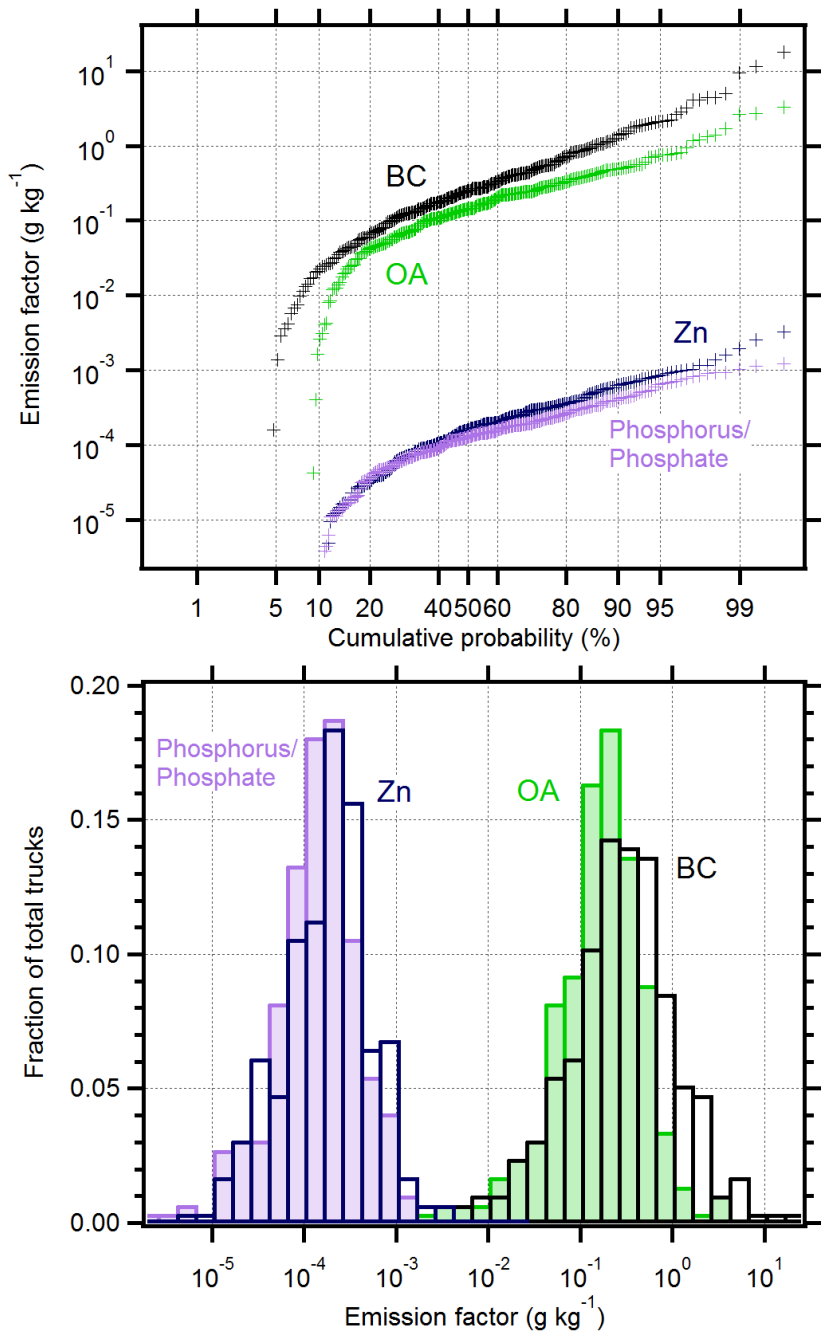

Figure 7. Emission factor log-probability plots (top) and distributions (bottom) for OA, BC, zinc, and phosphorus/phosphate.

trucks that may be useful in future applications of the SPAMS to source apportionment of ambient BC (Onasch et al., 2012).

\subsection{HD diesel truck emission factors}

Emission factors for individual chemical components of PM emitted by diesel trucks were evaluated for the entire population of trucks for which SP-AMS data were available, including low-emitting trucks not included in the mass spectral analysis presented above. Emission factors were calculated using Eq. (2), and species considered here include OA, $\mathrm{BC}$, zinc, and phosphorus/phosphate. Fleet-average emission factors for a sample of $293 \mathrm{HD}$ diesel trucks are presented in Table 1, and emission factor distributions are shown in Fig. 7. Note that trucks with zero or negative emission factors calculated using Eq. 2 are not included in this figure. For each of the emitted species considered here, between

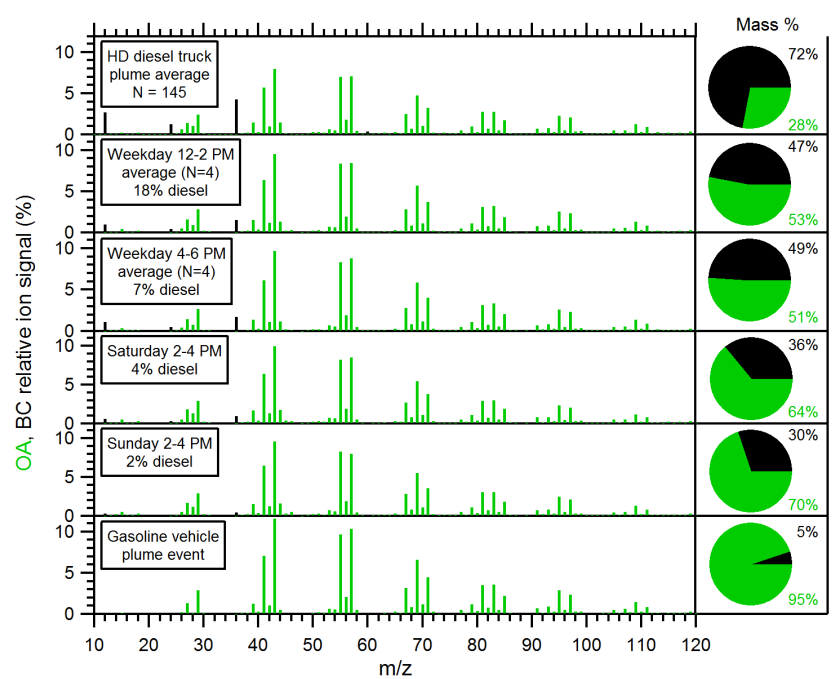

Figure 8. OA (green) and BC (black) mass spectra for high (top panel) to low (bottom panel) levels of diesel truck influence. Pie charts show relative contributions of $\mathrm{OA}$ and $\mathrm{BC}$ to total carbonaceous mass.

5 and $11 \%$ of the total measurements were for trucks with no detectable emissions. Both the $\mathrm{OA}$ and $\mathrm{BC}$ distributions are lognormal, though the $\mathrm{BC}$ distribution is more skewed than OA: $10 \%$ of $\mathrm{BC}$ and $\mathrm{OA}$ measurements accounted for 56 and $42 \%$ of total emissions of the respective pollutants. The fleet-average BC emission factor from the SP-AMS is $2.6 \pm 0.8$ times the value of the corresponding $\mathrm{OA}$ emission factor. Resulting $\mathrm{OA}$ to $\mathrm{BC}(\mathrm{OA} / \mathrm{BC})$ and $\mathrm{OC}$ to $\mathrm{BC}(\mathrm{OC} / \mathrm{BC})$ mass emission ratios for diesel trucks are $0.38 \pm 0.12$ and $0.31 \pm 0.10$, respectively. A prior vehicle emission study at the Caldecott tunnel estimated an OC/BC ratio for diesel trucks of 0.34, which is in good agreement with the ratio reported here (Ban-Weiss et al., 2008). Because diesel PM is predominantly carbonaceous, the sum of the $\mathrm{OA}$ and $\mathrm{BC}$ emission factors, $0.86 \pm 0.17 \mathrm{~g} \mathrm{~kg}^{-1}$, should provide a reasonable estimate of the $\mathrm{PM}_{2.5}$ emission factor for HD diesel trucks. Note that OA emission factors reported here are representative of the dilution conditions of the individual exhaust plumes sampled. Further dilution of exhaust to atmospheric levels may lead to volatilization of SVOC and a reduction in primary OA mass (Lipsky and Robinson, 2006; Robinson et al., 2007). Dilution ratios for the exhaust plume measurements reported here ranged from 60-3600, with an average $( \pm 95 \%$ confidence interval) of $650 \pm 60$. HD truck BC and $\mathrm{OA}$ emission factors presented here are approximately 3 times the values measured during a recent dynamometer test of an uncontrolled HD diesel truck operating on an urban dynamometer driving cycle, though similar OC/BC ratios were measured in both studies (May et al., 2014).

The ability of the SP-AMS to detect refractory PM components enabled the quantification of lubricant-derived trace element emission factors for individual HD trucks. 
Table 1. Fleet-average emission factors for HD diesel trucks $(N=293)$.

\begin{tabular}{lcccc}
\hline Species & $\begin{array}{c}\text { Emission factor } \pm 95 \% \\
\text { confidence interval }\end{array}$ & $\begin{array}{c}\text { Emission } \\
\text { factor units }\end{array}$ & $\begin{array}{c}\text { Emission factor } \\
\text { ratio to OA } \\
\text { emission factor } \\
(\mathrm{ppm})\end{array}$ & $\begin{array}{c}\text { Lubricating oil } \\
\text { elemental } \\
\text { weight fraction } \\
(\mathrm{ppm})^{\mathrm{a}}\end{array}$ \\
\hline $\mathrm{BC}$ & $0.62 \pm 0.17$ & $\mathrm{~g} \mathrm{~kg}^{-1}$ & & \\
OA & $0.24 \pm 0.04$ & $\mathrm{~g} \mathrm{~kg}^{-1}$ & & 1226 \\
$\begin{array}{l}\text { Zinc } \\
\text { Phosphorus/ } \\
\text { phosphate }\end{array}$ & $0.26 \pm 0.04$ & $\begin{array}{c}\mathrm{mg} \mathrm{kg}^{-1} \\
\mathrm{mg} \mathrm{kg}^{-1}\end{array}$ & $760 \pm 160$ & 985 \\
\hline
\end{tabular}

${ }^{a}$ Lubricating oil elemental composition reported for an SAE 15 W-40 CJ-4 diesel engine oil (Sappok and Wong, 2011).

Fleet-average emission factors for zinc and phosphorus/phosphate are reported in Table 1. Fleet-average emission factors for lubricant-derived elements are on the order of $0.1-1 \mathrm{mg} \mathrm{kg}^{-1}$ and are nearly 3 orders of magnitude lower than $\mathrm{OA}$ and $\mathrm{BC}$ emission factors. Emission factors reported here agree to within a factor of 4 with emission factors derived from a near-roadway study at a freeway in Los Angeles with high HD diesel truck activity (Ning et al., 2008). Emission factor distributions for zinc and phosphorus/phosphate, shown in Fig. 7, were lognormal and similar to OA in their degree of skewness.

The ratio of each trace element emission factor to the fleetaverage OA emission factor is presented in Table 1, along with the weight fraction of each element in a CJ-4 diesel engine oil as reported by Sappok and Wong (2011). Ratios define the emission factor for a given species to the emission factor for $\mathrm{OA}$, and reported units of ppm are equivalent to units of ppm used for bulk lubricating oil weight fractions. In general, the measured emission factors for these elements, when normalized to the OA emission factor, correspond well with their bulk oil concentrations. For both zinc and phosphorus/phosphate, OA normalized emissions are within $25 \%$ of lubricant concentrations. Furthermore, the relative magnitudes of emission factors for these trace species follow their abundances in lubricating oil. These findings further support the conclusion that lubricating oil, rather than diesel fuel, was the dominant source of exhaust OA emissions for trucks operating in the Caldecott tunnel. If a large fraction of OA emissions were derived from unburned or partially oxidized fuel, emission factors for these trace elements would be expected to be significantly lower when normalized to OA emissions.

\subsection{Comparison of diesel and gasoline exhaust PM}

Differences in PM emitted by gasoline and diesel motor vehicles were studied through a comparison of the chemical composition of carbonaceous aerosols measured in the tunnel during periods of varying diesel truck influence. Figure 8 shows the average $\mathrm{BC}$ and $\mathrm{OA}$ mass spectra and relative mass concentrations for six different sampling peri- ods/vehicle emission event types: individual diesel exhaust plume measurements (sample of 145 trucks considered for mass spectral analysis, top panel); 4 weekday $12-2$ p.m. and 4-6 p.m. IOPs (second and third panels); the Saturday and Sunday 2-4 p.m. IOPs (fourth and fifth panels); and a high PM-emitting gasoline vehicle (bottom panel). The panels are thus arranged from top to bottom in order of decreasing diesel engine influence. The relative contribution of diesel engines to vehicle-derived carbon for each IOP was calculated using measured $\mathrm{CO}_{2}$ concentrations and vehicle count data, and is included in the label for each IOP in Fig. 8. In general, PM contributions from individual gasoline vehicles were not discernible above tunnel background levels, and the direct characterization of PM composition for a representative sample of individual gasoline vehicle exhaust plumes was not possible. In the case of the gasoline vehicle plume event shown in Fig. 8, a clear OA signal was associated with the passing of a small truck. Concurrent time-resolved measurements of carbon monoxide, benzene, and toluene emissions support the conclusion that this high-emitting vehicle was equipped with a gasoline engine.

A main feature of Fig. 8 is the increasing trend in the $\mathrm{OA}$ to $\mathrm{BC}$ mass ratio with decreasing diesel influence. On average, diesel trucks were found to emit $2.6 \pm 0.8$ times more $\mathrm{BC}$ than $\mathrm{OA}$, with a corresponding $\mathrm{OA} / \mathrm{BC}$ ratio of $0.38 \pm 0.12$. For weekday $12-2$ p.m. and 2-4 p.m. sampling periods, when diesel trucks accounted for between 7 and $18 \%$ of total vehicle-derived carbon dioxide emissions, concentrations of $\mathrm{OA}$ and $\mathrm{BC}$ were similar $(\mathrm{OA} / \mathrm{BC}=1.1)$. The $\mathrm{OA} / \mathrm{BC}$ ratio further increased to 2.3 during the Sunday afternoon sampling period, when diesel trucks accounted for $2 \%$ of vehicle-derived carbon dioxide. For the high-emitting gasoline vehicle, PM emissions consisted primarily of OA. Fleet-average $\mathrm{OA}$ and $\mathrm{BC}$ emission factors for light-duty vehicles have been evaluated separately for this field campaign, and the corresponding $\mathrm{OA} / \mathrm{BC}$ emission ratio was $1.7 \pm 0.6$ (Dallmann et al., 2013). Thus, the increasing influence of gasoline vehicles on the measured $\mathrm{OA} / \mathrm{BC}$ ratio was observed in this study for weekend sampling periods when the influence of diesel trucks was lower. 
Table 2. Molar element ratios and OA / OC mass ratios for on-road motor vehicle emissions.

\begin{tabular}{lccc}
\hline Sampling period & $\mathrm{O} / \mathrm{C}$ & $\mathrm{H} / \mathrm{C}$ & $\mathrm{OA} / \mathrm{OC}$ \\
\hline $\begin{array}{l}\text { HD Diesel truck plume average } \\
(N=145)\end{array}$ & $0.06 \pm 0.02$ & $1.90 \pm 0.05$ & $1.24 \pm 0.03$ \\
$\begin{array}{l}\text { Weekday 12-2 p.m. average } \\
(N=4)\end{array}$ & $0.07 \pm 0.04$ & $1.89 \pm 0.05$ & $1.25 \pm 0.05$ \\
Weekday 4-6 p.m. average & $0.06 \pm 0.03$ & $1.91 \pm 0.04$ & $1.24 \pm 0.03$ \\
$(N=4)$ & & & \\
Saturday 2-4 p.m. & $0.09 \pm 0.04$ & $1.87 \pm 0.07$ & $1.28 \pm 0.06$ \\
Sunday 2-4 p.m. & $0.10 \pm 0.05$ & $1.86 \pm 0.08$ & $1.30 \pm 0.07$ \\
High-emission gasoline vehicle & $0.020 \pm 0.003$ & $1.99 \pm 0.01$ & $1.192 \pm 0.004$ \\
\hline
\end{tabular}

Though relative contributions of $\mathrm{BC}$ and $\mathrm{OA}$ varied significantly, there was very little difference in the corresponding mass spectra among sampling periods, as shown in Fig. 8. Here, the diesel truck BC and OA mass spectra are selected as reference mass spectra. Black carbon mass spectra shown in Fig. 8 all have similar distributions of carbon ions, with the $\mathrm{BC}$ signal dominated by $\mathrm{C}_{1}^{+}-\mathrm{C}_{3}^{+}$carbon ions in each case. Black carbon mass spectra across all sampling periods were highly correlated $\left(R^{2}>0.99\right.$ in all cases) with the reference diesel truck spectrum shown in the top panel of Fig. 8. Results from this study indicate that fuel-specific BC emission factors for diesel trucks are approximately 50 times greater than for LD gasoline vehicles (Dallmann et al., 2013). Consequently, diesel trucks contributed the majority of BC measured during the weekday $12-2$ p.m. and 4-6 p.m. sampling periods, though HD trucks accounted for only $7-18 \%$ of vehicle-derived carbon dioxide. Thus, the high degree of correlation observed between the weekday IOPs and diesel truck $\mathrm{BC}$ mass spectra is expected. Even small numbers of diesel trucks observed in the tunnel during the Sunday IOP still may have contributed significantly to measured $\mathrm{BC}$, though in this case light-duty vehicles are expected to be the dominant source of BC in the tunnel. The correspondence of the BC mass spectra for the Sunday sampling period and highemitting gasoline vehicle with the diesel truck mass spectrum therefore suggests carbon ion distributions measured with the SP-AMS are similar for gasoline and diesel vehicle-derived $\mathrm{BC}$. This in turn suggests that apportionment of gasoline versus diesel contributions to BC using SP-AMS carbon ion spectra may be difficult to achieve due to the similarity of the source profiles.

Similar to what was found for BC, varying levels of diesel truck traffic did not produce discernible differences in $\mathrm{OA}$ mass spectra measured with the SP-AMS. All OA spectra are dominated by ion fragments of the $\mathrm{C}_{\mathrm{x}} \mathrm{H}_{\mathrm{y}}^{+}$family, with prominent peaks at $m / z=41,43,55$, and 57. Organic aerosol mass spectra for the $2 \mathrm{hr}$ weekday and weekend sampling periods and the high-emitting gasoline vehicle were all wellcorrelated $\left(R^{2}>0.98\right)$ with the diesel truck OA mass spectrum.
Average $\mathrm{O} / \mathrm{C}, \mathrm{H} / \mathrm{C}$, and $\mathrm{OA} / \mathrm{OC}$ ratios are reported in Table 2, and were generally in good agreement across sampling periods considered here. The OA / OC and $\mathrm{O} / \mathrm{C}$ ratios were slightly higher during the Sunday IOP, possibly due to a higher relative contribution from more oxidized ambient PM during this sampling period. However, these differences were not significant and values are in line with prior characterizations of motor vehicle OA (Aiken et al., 2008). These results show, for the fleet of in-use vehicles measured at the Caldecott tunnel, OA emitted by gasoline and diesel vehicles produces similar mass spectra when characterized using the SP-AMS. As discussed previously, several lines of evidence indicate that lubricating oil was the dominant source of OA emitted by diesel trucks operating in the tunnel. Although there are differences in lubricating oil formulations used in gasoline and diesel engines, the chemical composition of the oils is similar, and distinct from both gasoline and diesel fuel (Rogge et al., 1993; Fujita et al., 2007). The similarity of OA mass spectra for gasoline vehicle-dominated sampling periods therefore suggests that a large fraction of OA emitted by gasoline vehicles is lubricant-derived as well. The high degree of similarity in the chemical composition of OA from both gasoline and diesel engines will again make it difficult to conduct ambient source apportionment studies to determine contributions to air pollution from these two important sources.

\section{The Supplement related to this article is available online at doi:10.5194/acp-14-7585-2014-supplement.}


Acknowledgements. The authors thank Drew Gentner, Gabriel Isaacman, Berk Knighton, Steven DeMartini, and the Caltrans staff at the Caldecott tunnel for their assistance. This publication was made possible by EPA grant RD834553. Its contents are solely the responsibility of the grantee and do not necessarily represent the official views of the EPA. Further, EPA does not endorse purchase of commercial products or services mentioned herein.

Edited by: N. Riemer

\section{References}

Aiken, A. C., DeCarlo, P. F., and Jimenez, J. L.: Elemental analysis of organic species with electron ionization high-resolution mass spectrometry, Anal. Chem., 79, 8350-8358, 2007.

Aiken, A. C., DeCarlo, P. F., Kroll, J. H., Worsnop, D. R., Huffman, J. A., Docherty, K. S., Ulbrich, I. M., Mohr, C., Kimmel, J. R., Sueper, D., Sun, Y., Zhang, Q., Trimborn, A., Northway, M., Ziemann, P. J., Canagaratna, M. R., Onasch, T. B., Alfarra, M. R., Prevot, A. S. H., Dommen, J., Duplissy, J., Metzger, A., Baltensperger, U., and Jimenez, J. L.: O / C and OM/OC ratios of primary, secondary, and ambient organic aerosols with high-resolution time-of-flight aerosol mass spectrometry, Environ. Sci. Technol., 42, 4478-4485, 2008.

Alfarra, M. R., Coe, H., Allan, J. D., Bower, K. N., Boudries, H., Canagaratna, M. R., Jimenez, J. L., Jayne, J. T., Garforth, A. A., Li, S.-M., and Worsnop, D. R.: Characterization of urban and rural organic particulate in the Lower Fraser Valley using two Aerodyne Aerosol Mass Spectrometers, Atmos. Environ., 38, 5745-5758, 2004.

Allan, J. D., Delia, A. E., Coe, H., Bower, K. N., Alfarra, M. R., Jimenez, J. L., Middlebrook, A. M., Drewnick, F., Onasch, T. B., Canagaratna, M. R., Jayne, J. T., and Worsnop, D. R.: A generalised method for the extraction of chemically resolved mass spectra from Aerodyne aerosol mass spectrometer data, J. Aerosol Sci., 35, 909-922, 2004.

Ban-Weiss, G. A., McLaughlin, J. P., Harley, R. A., Lunden, M. M., Kirchstetter, T. W., Kean, A. J., Strawa, A. W., Stevenson, E. D., and Kendall, G. R.: Long-term changes in emissions of nitrogen oxides and particulate matter from on-road gasoline and diesel vehicles, Atmos. Environ., 42, 220-232, doi:10.1016/j.atmosenv.2007.09.049, 2008.

Ban-Weiss, G. A., Lunden, M. M., Kirchstetter, T. W., and Harley, R. A.: Size-resolved particle number and volume emission factors for on-road gasoline and diesel motor vehicles, Aerosol Sci., 41, 5-12, doi:10.1016/j.jaerosci.2009.08.001, 2010.

Bell, M. L., Ebisu, K., Peng, R. D., Samet, J. M., and Dominici, F.: Hospital admissions abd chemical composition of fine particle air pollution, Am. J. Respir. Crit. Care Med., 179, 1115-1120, doi:10.1164/rccm.200808-1240OC, 2009.

Brandenberger, S., Mohr, M., Grob, K., and Neukom, H. P.: Contribution of unburned lubricating oil and diesel fuel to particulate emission from passenger cars, Atmos. Environ., 39, 6985-6994, doi:10.1016/j.atmosenv.2005.07.042, 2005.

Brook, R. D., Rajagopalan, S., Pope III, C. A., Brook, J. R., Bhatnagar, A., Diez-Roux, A. V., Holguin, F., Hong, Y., Luepker, R. V., Mittleman, M. A., Peters, A., Siscovick, D., Smith, S. C., Whit- sel, L., and Kaufman, J. D.: Particulate matter air pollution and cardiovascular disease. An update to the scientific statement from the American Heart Association, Circulation, 121, 2331-2378, doi:10.1161/CIR.0b013e3181dbece1, 2010.

Brugge, D., Durant, J. L., and Rioux, C.: Near-highway pollutants in motor vehicle exhaust: a review of epidemiologic evidence of cardiac and pulmonary health risks, Environ. Health, 6, 23, doi:10.1186/1476-069X-6-23, 2007.

Cadle, S. H., Mulawa, P. A., Ball, J., Donase, C., Weibel, A., Sagebiel, J. C., Knapp, K. T., and Snow, R.: Particulate emission rates from in-use high-emitting vehicles recruited in Orange County, California, Environ. Sci. Technol., 31, 3405-3412, 1997.

Canagaratna, M. R., Jayne, J. T., Ghertner, D. A., Herndon, S., Shi, Q., Jimenez, J. L., Silva, P. J., Williams, P., Lanni, T., Drewnick, F., Demerjian, K. L., Kolb, C. E., and Worsnop, D. R.: Chase studies of particulate emissions from in-use New York City vehicles, Aerosol Sci. Tech., 38, 555-573, 2004.

Canagaratna, M. R., Jayne, J. T., Jimenez, J. L., Allan, J. D., Alfarra, M. R., Zhang, Q., Onasch, T. B., Drewnick, F., Coe, H., Middlebrook, A., Delia, A., Williams, L. R., Trimborn, A. M., Northway, M. J., DeCarlo, P. F., Kolb, C. E., Davidovits, P., and Worsnop, D. R.: Chemical and microphysical characterization of ambient aerosols with the Aerodyne Aerosol Mass Spectrometer, Mass Spectrom. Rev., 26, 185-222, 2007.

Chirico, R., DeCarlo, P. F., Heringa, M. F., Tritscher, T., Richter, R., Prévôt, A. S. H., Dommen, J., Weingartner, E., Wehrle, G., Gysel, M., Laborde, M., and Baltensperger, U.: Impact of aftertreatment devices on primary emissions and secondary organic aerosol formation potential from in-use diesel vehicles: results from smog chamber experiments, Atmos. Chem. Phys., 10, 11545-11563, doi:10.5194/acp-10-11545-2010, 2010.

Chirico, R., Prevot, A. S. H., DeCarlo, P. F., Heringa, M. F., Richter, R., Weingartner, E., and Baltensperger, U.: Aerosol and trace gas vehicle emission factors measured in a tunnel using an Aerosol Mass Spectrometer and other online instrumentation, Atmos. Environ., 45, 2182-2192, doi:10.1016/j.atmosenv.2011.01.069, 2011.

Chow, J. C., Watson, J. G., Lowenthal, D. H., Chen, L. W. A., and Motallebl, N.: $\mathrm{PM}_{2.5}$ source profiles for black and organic carbon emission inventories, Atmos. Environ., 45, 5407-5414, 2011.

Cross, E. S., Sappok, A., Fortner, E. C., Hunter, J. F., Jayne, J. T., Brooks, W. A., Onach, T. B., Wong, V. W., Trimborn, A., Worsnop, D. R., and Kroll, J. H.: Real-time measurements of engine-out trace elements: application of a novel soot particle aerosol mass spectrometer for emissions characterization, J. Eng. Gas Turb. Power, 134, 072801, doi:10.1115/1.4005992, 2012.

Dallmann, T. R. and Harley, R. A.: Evaluation of mobile source emission trends in the United States, J. Geophys. Res., 115, D14305, doi:10.1029/2010JD013862, 2010.

Dallmann, T. R., Harley, R. A., and Kirchstetter, T. W.: Effects of diesel particle filter retrofits and accelerated fleet turnover on drayage truck emissions at the Port of Oakland, Environ. Sci. Technol., 45, 10773-10779, doi:10.1021/es202609q, 2011.

Dallmann, T. R., DeMartini, S. J., Kirchstetter, T. W., Herndon, S. C., Onasch, T. B., Wood, E. C., and Harley, R. A.: On-road measurement of gas and particle phase pollutant emission factors for individual heavy-duty diesel trucks, Environ. Sci. Technol., 46, 8511-8518, doi:10.1021/es301936c, 2012. 
Dallmann, T. R., Kirchstetter, T. W., DeMartini, S. J., and Harley, R. A.: Quantifying on-road emissions from gasolinepowered motor vehicles: accounting for the presence of medium and heavy-duty diesel trucks, Environ. Sci. Technol., 47, 1387313881, doi:10.1021/es402875u, 2013.

DeCarlo, P. F., Kimmel, J. R., Trimborn, A., Northway, M. J., Jayne, J. T., Aiken, A. C., Gonin, M., Fuhrer, K., Horvath, T., Docherty, K. S., Worsnop, D. R., and Jimenez, J. L.: Fielddeployable, high-resolution, time-of-flight aerosol mass spectrometer, Anal. Chem., 78, 8281-8289, 2006.

Donahue, N. M., Robinson, A. L., Stanier, C. O., and Pandis, S. N.: Coupled partitioning, dilution, and chemical aging of semivolatile organics, Environ. Sci. Technol., 40, 2635-2643, 2006.

Evans, J. S., Wolff, S. K., Phonboon, K., Levy, J. I., and Smith, K. R.: Exposure efficiency: an idea whose time has come, Chemosphere, 49, 1075-1091, 2002.

Freund, R., Wetzel, R., Shul, R., and Hayes, T.: Cross-section measurements for electron-impact ionization of atoms, Phys. Rev. A, 41, 3575-3595, 1990.

Fujita, E. M., Zielinska, B., Campbell, D. E., Arnott, W. P., Sagebiel, J. C., Gabele, P. A., Crews, W., Snow, R., Clark, N. N., Wayne, W. C., and Lawson, D. R.: Variations in speciated emissions from spark-ignition and compression-ignition motor vehicles in California's South Coast Air Basin, J. Air Waste Manage., 57, 705-720, 2007.

Gerlofs-Nijland, M. E., Dormans, J. A. M. A., Bloemen, H. J. T., Leseman, D. L. A. C., Boere, A. J. F., Kelley, F. J., Mudway, I. S., Jimenez, A. A., Donaldson, K., Guastadisegni, C., Janssen, N. A. H., Brunekreef, B., Sandstrom, T., van Bree, L., and Cassee, F. R.: Toxicity of coarse and fine particulate matter from sites with contrasting traffic profiles, Inhal. Technol., 19, 1055-1069, 2007.

Grieshop, A. P., Miracolo, M. A., Donahue, N. M., and Robinson, A. L.: Constraining the volatility distribution and gasparticle partitioning of combustion aerosols using isothermal dilution and thermodenuder methods, Environ. Sci. Technol., 43, 4750-4756, 2009.

Isaacman, G., Wilson, K. R., Chan, A. W. H., Worton, D. R., Kimmel, J. R., Nah, T., Hohaus, T., Gonin, M., Kroll, J. H., Worsnop, D. R., and Goldstein, A. H.: Improved resolution of hydrocarbon structures and constitutional isomers in complex mixtures using gas chromatography-vacuum ultraviolet-mass spectrometry, Anal. Chem., 84, 2335-2342, doi:10.1021/ac2030464, 2012.

Jayne, J. T., Leard, D. C., Zhang, X., Davidovits, P., Smith, K. A., Kolb, C. E., and Worsnop, D. R.: Development of an aerosol mass spectrometer for size and composition analysis of submicron particles, Aerosol Sci. Tech., 33, 49-70, 2000.

Jerrett, M., Burnett, R. T., Ma, R., Pope III, C. A., Krewski, D., Newbold, K. B., Thurston, G., Shi, Y., Finkelstein, N., Calle, E. E., and Thun, M. J.: Spatial analysis of air pollution and mortality in Los Angeles, Epidemiology, 16, 727-736, 2005.

Jimenez, J. L., Jayne, J. T., Shi, Q., Kolb, C. E., Worsnop, D. R., Yourshaw, I., Seinfeld, J. H., Flagan, R. C., Zhang, X., Smith, K. A., Morris, J. W., and Davidovits, P.: Ambient aerosol sampling using the Aerodyne aerosol mass spectrometer, J. Geophys. Res., 108, 8425, doi:10.1029/2001JD001213, 2003.
Kimmel, J. R., Farmer, D. K., Cubison, M. J., Sueper, D., Tanner, C., Nemitz, E., Worsnop, D. R., Gonin, M., and Jimenez, J. L.: Real-time aerosol mass spectrometry with millisecond resolution, Int. J. Mass Spectrom., 303, 15-26, 2011.

Kittelson, D. B., Watts, W. F., and Johnson, J. P.: On-road and laboratory evaluation of combustion aerosols - Part 1: Summary of diesel engine results, Aerosol Sci., 37, 913-930, 2006.

Kleeman, M. J., Riddle, S. G., Robert, M. A., and Jakober, C. A.: Lubricating oil and fuel contributions to particulate matter emissions from light-duty gasoline and heavy-duty diesel vehicles, Environ. Sci. Technol., 42, 235-242, 2008.

Kweon, C. B., Okada, S., Foster, D. E., Bae, M. S., and Schauer, J. J.: Effect of engine operating conditions on particlephase organic compounds in engine exhaust of a heavy-duty, direct-injection (DI) diesel engine, SAE Technical Paper Series, 2003-01-0342, 73-89, 2003.

Lapuerta, M., Hernandez, J. J., Ballesteros, R., and Duran, A.: Composition and size of disel particulate emissions from a commercial European engine tested with present and future fuels, P. I. Mech. Eng. D.-J. Aut., 217, 907-919, 2003.

Lipsky, E. M. and Robinson, A. L.: Effects of dilution on fine particle mass and partitioning of semivolatile organics in diesel exhaust and wood smoke, Environ. Sci. Technol., 40, 155-162, 2006.

Maricq, M. M.: Chemical characterization of particulate emissions from diesel engines: a review, Aerosol Sci., 38, 1079-1118, 2007.

Marshall, J. D., Teoh, S., and Nazaroff, W. W.: Intake fraction of nonreactive vehicle emissions in US urban areas, Atmos. Environ., 39, 1363-1371, 2005.

Massoli, P., Fortner, E. C., Canagaratna, M. R., Williams, L. R., Zhang, Z., Sun, Y., Schwab, J. J., Trimborn, A., Onasch, T. B., Demerjian, K. L., Kolb, C. E., Worsnop, D. R., and Jayne, J. T.: Pollution gradients and chemical characterization of particulate matter from vehicular traffic near major roadways: results from the 2009 Queens College Air Quality Study in NYC, Aerosol Sci. Tech., 46, 1201-1218, 2012.

Matthew, B. M., Middlebrook, A. M., and Onasch, T. B.: Collection efficiencies in an Aerodyne aerosol mass spectrometer as a function of particle phase for laboratory generated aerosols, Aerosol Sci. Tech., 42, 884-898, 2008.

May, A. A., Presto, A. A., Hennigan, C. J., Nguyen, N. T., Gordon, T. D., and Robinson, A. L.: Gas-particle partitioning of primary organic aerosol emissions: (1) gasoline vehicle exhaust, Atmos. Environ, 77, 128-139, doi:10.1016/j.atmosenv.2013.04.060, 2013.

May, A. A., Nguyen, N. T., Presto, A. A., Gordon, T. D., Lipsky, E. M., Karve, M., Guitierrez, A., Robertson, W. H., Zhang, M., Chang, O., Chen, S., Cicero-Fernandez, P., Fuentes, M., Huang, S.-M., Ling, R., Long, J., Maddox, C., Massetti, J., McCauley, E., Na, K., Pang, Y., Rieger, P., Sax, T., Truong, T., Vo, T., Chattopadhyay, S., Maldonado, H., Maricq, M. M., and Robinson, A. L.: Primary gas and PM emissions from light and heavy duty vehicles, Atmos. Environ., 88, 247-260, doi:10.1016/j.atmosenv.2014.01.046, 2014.

McLafferty, F. W. and Turecek, F.: Interpretation of Mass Spectra, University Science Books, Mill Valley, CA, 1993.

Mohr, C., Huffman, J. A., Cubison, M. J., Aiken, A. C., Docherty, K. S., Kimmel, J. R., Ulbrich, I. M., Hannigan, M., 
and Jimenez, J. L.: Characterization of primary organic aerosol emissions from meat cooking, trash burning, and motor vehicles with high-resolution aerosol mass spectrometry and comparison with ambient and chamber observations, Environ Sci. Technol., 43, 2443-2449, 2009.

Mozejko, P. and Sanche, L.: Cross sections for electron scattering from selected components of DNA and RNA, Radiat. Phys. Chem., 73, 77-84, doi:10.1016/j.radphyschem.2004.10.001, 2005.

Ning, Z., Polidori, A., Schauer, J. J., and Sioutas, C.: Emission factors of PM species based on freeway measurements and comparison with tunnel and dynamometer studies, Atmos. Environ., 42, 3099-3114, doi:10.1016/j.atmosenv.2007.12.039, 2008.

Onasch, T. B., Trimborn, A., Fortner, E. C., Jayne, J. T., Kok, G. L., Williams, L. R., Davidovits, P., and Worsnop, D. R.: Soot particle aerosol mass spectrometer: development, validation, and initial application, Aerosol Sci. Tech., 46, 804-817, 2012.

Pankow, J. F.: An absorption model of gas/particle partitioning of organic compounds in the atmosphere, Atmos. Environ., 28, 185-188, 1994.

Pope, C. A. and Dockery, D. W.: Health effects of fine particulate air pollution: lines that connect, J. Air Waste Manage., 56, 709-742, 2006.

Pottie, R. F.: Cross sections for ionization by electrons. I. Absolute ionization cross sections of $\mathrm{Zn}, \mathrm{Cd}$, and $\mathrm{Te}_{2}$. II. Comparison of theoretical with experimental values for atoms and molecules, J. Chem. Phys., 44, 916-922, doi:10.1063/1.1726842, 1966.

Robinson, A. L., Donahue, N. M., Shrivastava, M. K., Weitkamp, E. A., Sage, A. M., Grieshop, A. P., Lane, T. E., Pierce, J. R., and Pandis, S. N.: Rethinking organic aerosols: semivolatile emissions and photochemical aging, Science, 315, 1259-1262, 2007.

Robinson, A. L., Grieshop, A. P., Donahue, N. M., and Hunt, S. W.: Updating the conceptual model for fine particle mass emissions from combustion systems, J. Air Waste Manage., 60, 1204-1222, 2010.

Rogge, W. F., Hildemann, L. M., Mazurek, M. A., and Cass, G. R.: Sources of fine aerosol. 2. Noncatalyst and catalyst-equipped automobiles and heavy-duty diesel trucks, Environ. Sci. Technol., 27, 636-651, 1993.

Roth, C. M., Goss, K., and Schwarzenbach, R. P.: Sorption of a diverse set of organic vapors to diesel soot and road tunnel aerosols, Environ. Sci. Technol., 39, 6632-6637, 2005.

Sakurai, H., Tobias, H. J., Park, K., Zarling, D., Docherty, K. S., Kittelson, D., McMurry, P., and Ziemann, P. J.: On-line measurements of diesel nanoparticle composition and volatility, Atmos. Environ., 37, 1199-1210, 2003.

Salcedo, D., Laskin, A., Shutthanandan, V., and Jimenez, J. L.: Feasibility of the detection of trace elements in particulate matter using online high-resolution aerosol mass spectrometry. Aerosol Sci. Tech., 46, 1187-1200, doi:10.1080/02786826.2012.701354, 2012.
Sappok, A. and Wong, V.: Lubricant-derived ash properties and their effects on diesel particulate filter pressure drop performance, J. Eng. Gas Turb. Power, 133, 032805, doi:10.1115/1.4001944, 2011.

Schauer, J. J., Kleeman, M. J., Cass, G. R., and Simoneit, B. R. T.: Measurement of emissions from air pollutant sources $5, \mathrm{C}_{1}$ $\mathrm{C}_{32}$ organic compounds from gasoline-powered motor vehicles, Environ. Sci. Technol.,36, 1169-1180, doi:10.1021/es0108077, 2002.

Shah, S. D., Cocker, D. R., Miller, J. W., and Norbeck, J. M.: Emission rates of particulate matter and elemental and organic carbon from in-use diesel engines, Environ. Sci. Technol., 38, 2544 2550, doi:10.1021/es0350583, 2004.

Shields, L. G., Suess, D. T., and Prather, K. A.: Determination of single particle mass spectral signatures from heavy-duty diesel vehicle emissions for $\mathrm{PM}_{2.5}$ source apportionment, Atmos. Environ., 41, 3841-3852, 2007.

Slowik, J. G., Stainken, K., Davidovits, P., Williams, L. R., Jayne, J. T., Kolb, C. E., Worsnop, D. R., Rudich, Y., DeCarlo, P. F., and Jimenez, J. L.: Particle morphology and density characterization by combined mobility and aerodynamic diameter measurements. Part 2: Application to combustion-generated soot aerosols as a function of fuel equivalence ratio, Aerosol Sci. Tech., 38, 1206-1222, doi:10.1080/027868290903916, 2004.

Sonntag, D. B., Bailey, C. R., Fulper, C. R., and Baldauf, R. W.: Contribution of lubricating oil to particulate matter emissions from light-duty gasoline vehicles in Kansas City, Environ. Sci. Technol., 46, 4191-4199, 2012.

Spencer, M. T., Shields, L. G., Sodeman, D. A., Toner, S. M., and Prather, K. A.: Comparison of oil and fuel particle chemical signatures with particle emissions from heavy and light duty vehicles, Atmos. Environ., 40, 5224-5235, 2006.

Spikes, H.: The history and mechanisms of ZDDP, Tribol. Lett., 17, 469-489, 2004.

Tawara, H. and Kato, T.: Total and partial ionization cross sections of atoms and ions by electron impact, Atom. Data Nucl. Data, 36, 167-353, 1987.

Tobias, H. J., Beving, D. E., Ziemann, P. J., Sakurai, H., Zuk, M., McMurry, P., Zarling, D., Waytulonis, R., and Kittleson, D. B.: Chemical analysis of diesel engine nanoparticles using a nanoDMA/thermal desorption particle beam mass spectrometer, Environ. Sci. Technol., 35, 2233-2243, 2001.

Tornehed, P. and Olofsson, U.: Lubricant ash particles in diesel engine exhaust. Literature review and modeling study, P. I. Mech. Eng. D.-J. Aut., 255, 1055-1066, 2011.

Worton, D. R., Isaacman, G., Gentner, D. R., Dallmann, T. R., Chan, A. W. H., Kirchstetter, T. W., Wilson, K. R., Harley, R. A., and Goldstein, A. H.: Lubricating oil dominates primary organic aerosol emissions from motor vehicles, Environ. Sci. Technol. 48, 3698-3706, doi:10.1021/es405375j, 2014. 